\title{
On the Relationship of Multiple Intelligences With Listening Proficiency and Attitudes Among Iranian TEFL University Students
}

\section{Ma'ssoumeh Bemani Naeini and Ambigapathy Pandian}

Gardner's (1983) Multiple Intelligences Theory (MIT) has been found to have profound implications in teaching English as a foreign language (TEFL) in that it provides a way for teachers to recognize learners' individual cognitive and affective differences by providing favorable motivational conditions for learning. However, little investigation has focused on the domains of cognition and affect in a single study. Therefore, this study investigates two facets: the relationship of Multiple Intelligences (MIs) with listening among Iranian TEFL university students and the possible relationship between the type of intelligence the students fall into and their attitudes toward learning English. In this study, McKenzie's (1999) MI Inventory was used to identify 60 participants' preferred intelligences. The participants comprised an intact group randomly assigned to the experiment. A Likert-type questionnaire was employed to elicit data about participants' levels of personality traits that accounted for their attitudes to language-learning. Also, the participants' listening comprehension proficiency was measured using the listening section of a retired TOEFL test. Data analysis using Pearson correlation revealed no significant relationship between the score of listening and any of the MIs. Similarly, the results indicated no significant difference between MIs and attitudes.

On a trouvé que la théorie des intelligences multiples de Gardner (1983) avait de profondes conséquences sur l'enseignement de l'anglais comme langue étrangère (ALE) dans le sens qu'elle offre aux enseignants une façon de reconnaître les différences cognitives et affectives des apprenants en créant des conditions d'apprentissage favorables et motivantes. Toutefois, peu de recherche a touché à la fois l'aspect cognitif et l'aspect affectif lors de la même étude. Cette étude a donc deux facettes : le rapport entre les intelligences multiples et l'écoute chez les étudiants iraniens en ALE à l'université, et le rapport possible entre le type d'intelligence de l'étudiant et son attitude face à l'apprentissage de l'anglais. Nous avons eu recours au répertoire des intelligences multiples de McKenzie (1999) pour identifier les intelligences préférées de 60 participants. Ceux-ci constituaient un groupe intact choisi au hasard pour participer à l'expérience. Un questionnaire du type Likert a servi dans la cueillette de données portant sur les traits de caractère qui expliquaient leur attitude face à l'apprentissage d'une langue. De plus, nous 
avons mesuré la compréhension auditive avec la section portant sur l'écoute d'un test TOEFL qui ne sert plus. L'analyse des données avec la corrélation de Pearson $n^{\prime}$ a révélé aucun rapport significatif entre le résultat à l'écoute et les intelligences multiples. De la même façon, les résultats n'ont indiqué aucune différence significative entre les intelligences multiples et les attitudes.

\section{Introduction}

From the psychological perspective, Gardner $(1983,1993)$ called attention to neurological studies that underpin effective theoretical bases for language learning or teaching. Proposing his Multiple Intelligences Theory (MIT), Gardner indicated that the human brain stored various types of learning elements in particular areas of the brain and that various types of learning happened as a result of synaptic connections between cells in certain areas of the brain. According to this theory, we are all born with all types of intelligence, which are necessary for us to function effectively in society. Nevertheless, each person develops some of these intelligences more strongly than others, and children develop inclinations toward some of the intelligences at an early age (Armstrong, 2000). Gardner (1991) maintained that because human cognitive ability is pluralistic rather than unitary, teachers should provide a variety of opportunities for learners so as to let each individual use his or her own area of strength to master the learning task. In Gardner's model, intelligence is viewed as a composite of nine intelligences, each of which may function independently (see Table 1).

On the other hand, as indicated by Feyten (1991), it was not until the 1940s that listening comprehension gained importance in the field of languagelearning. Since then, as the cornerstone of many theories of language acquisition and instruction, listening comprehension has been taken as a fundamental basis for the development of language proficiency. The principal assumption underlying such theories is that language acquisition is a complicated mental process during which linguistic items and rules are internalized through exposure to authentic texts and ultimately to comprehensible input that challenges the language-learner during listening tasks (Krashen, 1982). In addition, listening is important in the sense that it underlies understanding and speaking (Carter \& Nunan, 2001; Chastain, 1988).

Moreover, insights into EFL/ESL-learning during recent decades have informed us that language-learning is primarily a learner/learning-oriented process; thus more attention should be paid to learners' beliefs and attitudes toward language-learning (Nunan, 1988). As suggested by a number of studies (Brown, 2000; Carter \& Nunan, 2001), one should not neglect the important role of affective factors when investigating the factors involved in language-learning in general and more specifically in listening comprehension. Among these factors, the roles of motivation and attitudes are reported 


\begin{tabular}{|c|c|c|}
\hline Intelligence & People's Ability & People's Typical Interests \\
\hline $\begin{array}{l}\text { Verbal/ } \\
\text { Linguistic }\end{array}$ & $\begin{array}{l}\text { Effective use of language and } \\
\text { good knowledge of words }\end{array}$ & $\begin{array}{l}\text { Like to read, play with words, write, do } \\
\text { crossword puzzles, and invent word games }\end{array}$ \\
\hline $\begin{array}{l}\text { Visual/ } \\
\text { Spatial }\end{array}$ & $\begin{array}{l}\text { Sensitivity to color and } \\
\text { design, sensitivity to graphic } \\
\text { forms, good at finding spatial } \\
\text { relations }\end{array}$ & Like to do art, read maps and follow directions \\
\hline $\begin{array}{l}\text { Kinesthetic/ } \\
\text { Bodily }\end{array}$ & $\begin{array}{l}\text { Good at physical/bodily } \\
\text { coordination }\end{array}$ & $\begin{array}{l}\text { Like to move to learn, enjoy feeling their } \\
\text { bodies move, may be athletes or sports } \\
\text { enthusiasts, and are physically active }\end{array}$ \\
\hline $\begin{array}{l}\text { Logical/ } \\
\text { Mathematical }\end{array}$ & $\begin{array}{l}\text { Effective use of numbers, } \\
\text { ability to deduce conclusions, } \\
\text { ability to see cause and effect }\end{array}$ & $\begin{array}{l}\text { Like math, computer programming, logic } \\
\text { puzzles, and problem-solving }\end{array}$ \\
\hline Interpersonal & $\begin{array}{l}\text { Ability to understand others, } \\
\text { their intentions and moods }\end{array}$ & $\begin{array}{l}\text { Enjoy talking ideas over with other people, } \\
\text { like collaborating on projects, and enjoy } \\
\text { meeting and spending time with people }\end{array}$ \\
\hline Intrapesonal & $\begin{array}{l}\text { Knowledge of the self and } \\
\text { ability to learn on their own }\end{array}$ & $\begin{array}{l}\text { Like to develop their own thinking by being } \\
\text { alone }\end{array}$ \\
\hline $\begin{array}{l}\text { Musical/ } \\
\text { Rhythmic }\end{array}$ & $\begin{array}{l}\text { Sensitive to melody and } \\
\text { rhythm }\end{array}$ & $\begin{array}{l}\text { Enjoy and appreciate musical performances, } \\
\text { may play an instrument or sing, enjoy melodic } \\
\text { speech and writing, and may compose }\end{array}$ \\
\hline Naturalist & $\begin{array}{l}\text { Ability to know and care } \\
\text { about nature }\end{array}$ & $\begin{array}{l}\text { Enjoy being outside, seeing and enjoying } \\
\text { patterns in nature, are proficient at } \\
\text { understanding the natural world }\end{array}$ \\
\hline Existential & $\begin{array}{l}\text { Reflects on the meaning of } \\
\text { life, concerned with questions } \\
\text { regarding the human } \\
\text { condition such as the } \\
\text { meaning of life, death, and } \\
\text { love }\end{array}$ & $\begin{array}{l}\text { Like religion, transcendent, mysticism; } \\
\text { practice meditation; study Zen stories, and } \\
\text { learn about the diverse types of religion such } \\
\text { as Buddhism }\end{array}$ \\
\hline
\end{tabular}

as of crucial value to the extent that as interacting variables, language-learning and psychological factors can positively affect one another (Brown, 1973; Huitt, 2004; Powers \& Sanchez, 1982). For example, Rifkin (2000) attributed learners' success or failure in mastering a foreign language to their beliefs and preferences about language-learning.

\section{The Problem}

Although English teaching and learning is important in Iran, and the number of learners of English as a foreign language (EFL) continues to increase (Talebinezhad \& Sadeghi Beniss, 2005), listening skills are not targeted as heavily in Iranian EFL classes as are reading skills. This seems to be because 
despite the high rate of positive attitudes found among Iranian EFL learners (Hassanpour, 1999; Sadighi \& Zarafshan, 2006), the learners may not be capable of communiating in English after graduating from university, mainly because of listening deficiency. As pointed out by Vandergrift (2004), difficulty in learning to listen well can be attributed to the implicit nature of the skill or to the unrealistic assumption that this skill will automatically develop from other skills as a result of a transfer of training; hence there is a need for strategy-training practice to assist learners. In this regard, EFL teaching and learning in Iran is no exception.

In Iran, in addition to the international call for a change in teaching strategies to achieve the goal of enhancing listening proficiency (Goh, 2000; Hassan, 2000; Vandergrift, 2002), locally it has also been realized that focusing on traditional methods may well ultimately result in depriving students of becoming actively involved in natural language use, which can make them passive. In class, communication is often only one way, that is, between teacher and student. In English classes, it seems usually to be the teacher who initiates discussions, whereas students are passive listeners and receivers. Little active listening is practiced in the classroom (Ghasemi, 1996; Mazandarani, 1998; Sadeghi Beniss, 2005). So as a result of excessively teacherdirected instruction, students do not receive sufficient opportunities to engage in class listening activities; thus their self-expression is suppressed, which leads to reduced interest and motivation. The source of this problem may ultimately be attributed to neglecting learners' individual differences.

As a result of this neglect, learners are not sufficiently motivated to develop positive attitudes toward learning English in general and listening in particular (Akbari \& Hosseini, 2008). Ironically, this problem still exists at a time when recent trends favoring individualization in education have emerged to recognize and respect individual values and differences in terms of human physical, cognitive, and affective variables. Among other concepts, intelligence has been addressed in language teaching/learning as one of the relevant variables (Armstrong, 2000; Christison, 1996, 1998; Christison \& Kennedy, 1999; Lin, 2000; McKenzie, 2002; Reid, 1998; Sadler-Smith, 2001; Smith, 2002; Teele, 2004; Williams \& Burden, 1997; Willingham, 2004). In addition, Horwitz (1995) asserted, "successful language learning depends on the emotional responses of the learner as well as their cognitive abilities" (p. 576). Therefore, it is of crucial value to examine both affect and intelligence in relation to the process of second/foreign-language learning.

\section{Background to the Study}

For the past decades, the role of attitude as an important affective variable in the process of language-learning has appealed to many researchers. For example, Sarnoff (1970) defined attitude as "a disposition to react favorably or unfavorably to a class of objects" (p. 279). Holmes (1992) stated, "people 
develop attitudes towards languages which reflect their views about those who speak the languages, and the contexts and functions with which they are associated" (p. 346). Accordingly, as pointed out by Brown (2000), "the affective domain is the emotional side of human behavior, and it may be juxtaposed to the cognitive side" (p. 143). Therefore, learning a language like any other behavior reflects and is affected by both cognition and affect. In this regard, Horwitz (1995) argued that the process of language-learning required a level of personal engagement on the part of adult languagelearners: they may make progress in foreign-language learning if they develop a perception of their personality.

A number of affective or emotional variables form an individual's personality, influencing the process of foreign-language learning. According to Brown (2000), self-esteem (self-image), inhibition, risk-taking, ego permeability, and tolerance of ambiguity are among the variables that may account for EFL learners' success or failure. Drawing on Bloom's (Krathwohl, Bloom \& Masia, 1964) taxonomy about notions of receiving, responding, and valuing, Brown found these aspects of the affective domain fundamental for second-language learning. In his words, "understanding how human beings feel and respond and believe and value is an exceedingly important aspect of a theory of second language acquisition" (p. 144).

Self-esteem has been described as "a personal judgment of worthiness that is expressed in the attitudes that individuals hold towards themselves" (Coopersmith, 1967, pp. 4-5). Inhibition is another personality factor that is closely related to the notion of self-esteem in that by building sets of defenses around their ego, humans try to protect themselves from threats to their self-esteem. Hence the lower the inhibitions (defenses), the higher is the self-esteem and the stronger is the ego. On the other hand, those with a weaker ego who also lack sufficient self-confidence tend to develop thicker (less permeable) ego boundaries. Thus ego permeability has been described by Ellis (1994) as "the extent to which L2 learners perceive their L1 to have fixed and rigid or permeable and flexible boundaries and therefore the extent to which they are inhibited" (p. 232). These factors, as the components of the notion of language ego, proposed by Ehrman (1996) can be well related to second-language acquisition.

Language learners are also identified with risk-taking as another attribute of their personality. "Risk takers show less hesitancy, are more willing to use complex language, and are more tolerant of errors. They are less likely to rehearse before speaking" (Ellis, 1994, p. 518). Brown (2000) views risktaking as an important factor that is related to inhibition and self-esteem in the sense that those with high self-esteem are not afraid of taking risks even if they are laughed at for making mistakes. As Brown put it, "learners have to be able to gamble a bit, to be willing to try out hunches about the language and take the risk of being wrong" (149). 
Tolerance of ambiguity, also defined as a learning style, refers to the extent of willingness to withstand ideas, propositions, and facts that contradict one's system of beliefs or knowledge. In the process of language learning, those learners are successful who can more easily internalize vocabulary, grammatical rules, and cultural aspects of a foreign language that are incongruent with their own existing linguistic, cognitive, and affective systems (Brown, 2000). As Ellis (1994) stated, tolerance of ambiguity "entails an ability to deal with ambiguous new stimuli without frustration and without appeals to authority" (p. 518).

In addition, over the last two decades there has been a shift from teacheroriented approaches toward calls for providing a flexible, needs-oriented, and personalized learning environment in which there is more focus on learners and learning rather than on teachers and teaching (Nunan, 1988). In the field of individual differences, educational research informs us that reflecting their individual characteristics, learners process and represent knowledge in diverse particular ways, adopting varied styles and strategies. The literature also tells us that such differences have been found to predict learners' performance; hence there is reason for teachers to adapt their teaching strategies to those varied traits (Chamot \& Kupper, 1989; Cohen, 2003; O'Malley \& Chamot, 1990; Oxford, 1990). Thus to develop a learner-centered curriculum, teachers are encouraged to understand better their students' traits and how they process information. To do so, some ideas like MIT have been integrated into language pedagogy from disciplines like psychology.

\section{Support for the Implications of MIT}

As for the implications of MIT in education and particularly in TEFL, the theory has gained remarkable approval for application in EFL/ESL teaching situations (Armstrong, 2000; Campbell, 1997; Christison, 1996, 1998; Christison \& Kennedy, 1999; Lazear, 1999). For example, it has been proposed that teachers should provide for learning situations that accommodate learners' diverse learning characteristics, thus improving their language-learning performance. Teachers should be able to teach to learners' strengths in terms of multiple intelligences (MIs) because, as recommended by Gardner (1993), the use of varied educational approaches and a variety of activities-like games, images, stories, music, and so on in an integrated system of educationwould take individual differences into account, as a result of which teachers might successfully engage students' natural talents (Gardner). Then the next step would be adapting instruction to such differences in a manner designed to give all learners the opportunity to fulfill their potential (Christison; Lazear).

In addition, Arnold and Fonseca (2004) argued in favor of the application of MIT in the EFL classroom on the basis of support from brain science. They maintained that Gardner's MIT had profound implications for language 
teaching and learning. They proposed that based on the diverse types of intelligences, one might well develop new frames for language-teaching. For example, teachers might adopt MIT as a tool to plan language-learning tasks around diverse intelligences. As they put it,

For instance, an activity such as that of writing the lyrics of a song implies the use of linguistic and musical intelligences. In a role-play where learners may need to express their feelings while being considerate of the feelings of others, linguistic, intrapersonal and interpersonal talents are needed. In a task where learners need to mime the title of a film for others to guess, the bodily kinesthetic and interpersonal abilities are brought into play. (p. 125)

Similarly, there is strong support from neurobiological studies for the importance of affect in learning. For example, Schumann (1997) commented in his work to develop a language acquisition model that the "brain stem, limbic and frontolimbic areas, which comprise the stimulus appraisal system, emotionally modulate cognition such that, in the brain, emotion and cognition are distinguishable but inseparable. Therefore, from a neural perspective, affect is an integral part of cognition" (p. 232). Thus in order to optimize learners' cognitive functioning, their affective dimension should also be taken into account. Such a perspective supports the incorporation of MIT as an effective tool in foreign-language teaching. As proposed by Gardner $(1983,1993)$, human beings as multidimensional subjects need to develop all their other abilities including, for example, the physical, artistic, and spiritual dimensions, rather than only their linguistic and logical aspects.

\section{Relevant Studies}

Despite the approval that MIT has received for application in EFL/ESL teaching situations (Armstrong, 2000; Campbell, 1997; Christison, 1996, 1998; Christison \& Kennedy, 1999; Lazear, 1999), not many studies have practically implemented the theory in EFL contexts.

In Iran, educators and researchers did not until the last decade begin to explore the role of MIs in applied linguistics. They began to study the contribution of this theory to English proficiency, reading, writing, vocabulary, and strategy use (Akbari \& Hosseini, 2008; Hosseini, 2003; Marefat, 2007; Razmjoo, 2008, Razmjoo, Sahragard, \& Sadri, 2009; Yeganehfar, 2005). However, there is still a need to examine some other aspects of L2 learning like listening proficiency, which one may hypothesize is connected to MIs.

To our knowledge, only a few recent research studies have been carried out on the role of MIs in listening comprehension. The results of a study by Mahdavy (2008) revealed that although all the intelligences showed positive correlations with performance on listening comprehension tests, only linguistic intelligence was statistically significant as a predictor of listening 
proficiency, no matter whether a TOEFL or an IELTS listening proficiency test was administered. In another study, Yeganehfar (2005) studied the relationship of MIs with language proficiency. She found an acceptable correlation between listening and speaking skills and intrapersonal intelligence.

As for the realm of attitudes, Iranian researchers and educators have shown more interest. For example, Sedaghat (2001) investigated the effects of attitude, motivation, and level of proficiency on the use of listening comprehension strategies by female Iranian EFL students. He came to the conclusion that students with positive attitudes used metacognitive, memory, cognitive, compensation, and social strategies more than those who had negative attitudes. However, he found no significant difference between either negative or positive attitudes and affective strategies. In another study, Sadighi and Zarafshan (2006) reported that Iranian university students were apt to employ metacognitive, social, affective, and compensation strategies more frequently than memory and cognitive strategies. They also found a significant relation between attitude and the use of language-learning strategies, such that those students with positive attitudes used such strategies more frequently than those with negative attitudes toward learning English. Among other studies is one by Hayati and Ostadian (2008), who found a positive relationship between self-esteem and listening comprehension. They concluded that self-esteem played a more important role in Iranian women's EFL listening comprehension than in men's. Moreover, in an attempt to find the relationship between Iranian ESP students' attitudes and their use of learning strategies, Hassanpour (1999) found no significant difference, although the mean number of strategies used by the students with a positive attitude was higher than that of those who had a negative attitude toward learning English. In yet another study, Rahimi and Abedini (2009) recognized the importance of individual characteristics in the recent paradigm shift toward learner-oriented instruction. In this regard, they conducted a study that explored the role of EFL learners' self-efficacy in their listening test performance. They collected data from 61 freshmen undergraduate learners of English. The analyzed data indicated that listening comprehension was significantly related to self-efficacy.

However, in spite of the numerous studies carried out in the realms of cognitive and affective variables, to our knowledge barely any study in the Iranian context has investigated the role of attitudes in terms of personality variables. In only one recent work, Hassaskhah (2009) attempted to look at EFL learners' affect from the perspective of MIT. Having run a quantitative/qualitative study involving 672 Iranian English and non-English majoring students and their 26 English teachers, Hassaskhah found that although a relationship existed between discipline and type of intelligence, the activities observed in classrooms had a relationship with neither teachers' nor students' intelligence types, which negatively affected both teachers' and 
students' levels of satisfaction. It is in this context that the present study focuses on the possible relationship between cognition and affect, perhaps to compensate in some degree for the lack of such studies in Iranian settings.

\section{Research Objectives and Questions}

With respect to the issues discussed above, two main problems appear salient. First, EFL learners in Iran have shown a deficiency in listening comprehension. Second, EFL teaching methodology in Iran does not meet individual differences such as MIs and attitudes. Based on the hypothesis that aspects of listening comprehension might be connected to learners' MIs and their attitudes, the present study investigates the possible relationships between Iranian EFL learners' MI profiles and their scores on listening comprehension, as well as their relationships with the factor of attitude (selfimage, inhibition, risk-taking, ego permeability, and tolerance to ambiguity). With these research problems in mind, the research questions are as follows.

1. What is the relationship between MIs and listening comprehension proficiency?

2. What is the relationship between MIs and participants' attitudes toward learning English in terms of personality variables?

\section{Methodology}

Participants. The participants in this study comprised a total of 60 university students (50 females and 10 males, age range 19-26 years) majoring in TEFL at Islamic Azad University-Mashhad Branch. They were sophomore students who were registered to attend Conversation 2 classes (for four credit units) after successfully completing Conversation 1 . So they had some background ideas about the nature and the regular procedures of such courses of study. They were required to attend classes for three hours a week for a complete semester of 16 weeks. Moreover, as a partial requirement of the course, they needed to access the language laboratory for four hours a week during the same semester. Because the principal researcher had to follow the protocol of the university, she had no control over deciding the number of participants invited to join. Thus the intact group of the study was randomly assigned to the experiment by decisions of the university administration.

Instruments. One of the instruments used in this study was the listening section of a retired TOEFL containing 50 questions designed to measure the participants' listening comprehension proficiency. The test was reported to have a reliability rate of 0.86 as measured by Cronbach alpha (CA). Another instrument used for the study was a questionnaire; all participants answered the questions, which encompassed a number of opinions about the participants' attitudes toward learning English. For this purpose, a Likerttype questionnaire with five-scale responses about the five kinds of personality traits (self-image, inhibition, risk-taking, ego permeability, and 
Table 2

Descriptive Statistics for All Participants

\begin{tabular}{lll}
\hline Statistics & Listening Proficiency & Attitudes \\
\hline Number & 60 & 60 \\
Mean & 26.83 & 13.75 \\
Median & 26.00 & 13.00 \\
Mode & 26 & 13.00 \\
Standard deviation & 5.981 & 2.175 \\
Variance & 35.766 & 4.73 \\
Minimum & 16 & 10.00 \\
Maximum & 40 & 18.00 \\
\hline
\end{tabular}

ambiguity tolerance) was adopted from Orwig (1999). The reliability index of the questionnaire had been estimated at $0.8+\mathrm{CA}$. As for construct validity, factor analysis revealed a value of 0.80 . In addition, in order to identify the participants' MI profiles, a MI-based inventory was adopted from McKenzie (1999). The content validity of the questionnaires was verified by a panel of experts consisting of three academic members of the English department, with an average of 15 years of experience teaching and doing research in applied linguistics.

Procedure and data analysis. The participants in the study were first rated for their English listening proficiency by their taking a TOEFL test at the beginning of the semester. At the same time, their varied types of attitude toward English-learning in terms of personality traits were examined by having them complete the related questionnaire of the study. Of a total of 27 questions, each was rated as strongly agree, agree, neither agree nor disagree, disagree, and strongly disagree, and also given point values of $8,6,4,2$, and 0 respectively. Five clusters were derived from the items based on the personality traits involved. There were eight items in each cluster, some of which overlapped. By adding the points in each column - that is, attributes of personality-scores for language-learning attitudes were calculated. Next these scores were evaluated as high (48-64), above average (36-47), average (16-35), and low (0-15). Finally, to feed the data into the computer, a range of 1-4 was chosen to code the rates of low, average, above average, and high respectively.

The participants were also given the MI Inventory to identify their MI profiles based on the type of intelligence for which they obtained the highest score. Care was taken throughout the research procedure to clarify every item for the students. They were also assured that the information would be kept confidential and used for research purposes only. Of all nine intelligence profiles, the participants were divided into eight groups at varied rates. The only intelligence profile excluded from the study was existential, because only one participant gained the highest score in that intelligence and 
Table 3

Descriptive Statistics of Attitudes in Terms of Personality Variables

\begin{tabular}{lccccc}
\hline Statistics & $S I$ & Inh. & $R T$ & $E P$ & $A T$ \\
\hline $\mathrm{N}$ & 60 & 60 & 60 & 60 & 60 \\
Mean & 2.63 & 2.40 & 2.98 & 2.78 & 2.95 \\
Standard Deviation & 0.610 & 0.887 & 0.624 & 0.490 & 0.622 \\
Variance & 0.372 & 0.786 & 0.390 & 0.240 & 0.387 \\
Frequency & & & & & \\
$\quad$ L. & 0 & 9 & 0 & 0 & 0 \\
Avg. & 26 & 19 & 12 & 15 & 13 \\
AA & 30 & 7 & 11 & 43 & 37 \\
H & 4 & 15.0 & 0 & 2 & 10 \\
Percent & 0 & 41.7 & 20.0 & 25.0 & 21.7 \\
L & 43.3 & 31.7 & 61.7 & 71.7 & 61.7 \\
Avg. & 50.0 & 11.7 & 18.3 & 3.3 & 16.7 \\
AA & 6.7 & & & & \\
H & & & & & \\
\hline
\end{tabular}

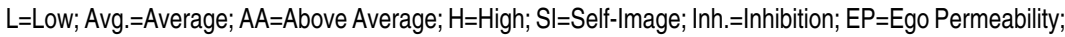

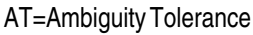

so could not be considered as a group. This particular participant was added to the visual group because her second-highest score was obtained for that intelligence.

The collected data were first analyzed descriptively using measures of central tendency. Then the Pearson Correlation Analysis was conducted to explore the possible relationship between intelligence profiles and both the participants' listening comprehension scores and their attitudes towards English. Pearson product-moment correlation coefficient $(r)$ was used for parametric statistic analysis. This technique is used to describe the strength and direction of the linear relationship between two continuous variables (Pallant, 2007). The reason for using it for this study was to deal with one sample (60 participants) with scores on different measures; that is, MI Inventory, listening comprehension test, and attitudes questionnaire. The results of the correlation inform us about the strength of such relationships, which can be interpreted from the size of the value of the correlation coefficient. This value ranges from -1.00-1.00. A correlation of 0 indicates no relationship at all. For values between 0 and 1, Cohen (1988) interprets $r=.10-.29$ as small; $r=.30-.49$ as medium, and $r=.50-1.0$ as large values of relationship. 
Table 4

Descriptive Statistics of Attitude and Listening Comprehension by Intelligence Groups

\begin{tabular}{lccccc}
\hline Participants & $\begin{array}{c}\text { Mean of } \\
\text { Listening }\end{array}$ & $\begin{array}{c}\text { SD of } \\
\text { Listening }\end{array}$ & $\begin{array}{c}\text { Mean of } \\
\text { Attitudes }\end{array}$ & $\begin{array}{c}\text { SD of } \\
\text { Attitudes }\end{array}$ & $N$ \\
\hline Linguistic & 25.67 & 6.442 & 12.55 & 1.130 & 9 \\
Visual & 29.40 & 6.518 & 13.70 & 2.00 & 10 \\
Kinesthetic & 25.25 & 3.845 & 13.62 & 2.92 & 8 \\
Logical & 28.43 & 8.182 & 13.85 & 1.214 & 7 \\
Interpersonal & 27.60 & 6.670 & 14.70 & 2.311 & 10 \\
Intrapersonal & 25.50 & 5.642 & 13.70 & 2.26 & 10 \\
Musical & 27.00 & 5.657 & 12.50 & 0.707 & 2 \\
Naturalist & 24.75 & 2.217 & 15.00 & 3.55 & 4 \\
\hline
\end{tabular}

$\mathrm{SD}=$ Standard Deviation; $\mathrm{N}=$ Number .

\section{Results and Discussion}

The results of the descriptive analysis for all the participants' scores in listening proficiency and their attitudes are presented in Table 2. The findings indicate an overall mean score of 26.83 out of 50, with an $S D$ of 5.981 on listening proficiency. As for attitudes, there was a mean score of 13.75 out of 20, with a $S D$ of 2.175 .

Moreover, according to the information in Table 3, the highest mean value of attitude can be assigned to risk-taking, followed by ambiguity tolerance, ego permeability, self-image, and inhibition respectively. Table 3 also indicates that the highest rate of low attitude was attributed to inhibition $(15 \%)$. Self-image was rated as average for $43.3 \%$ of the participants; $71.7 \%$ of the participants rated above average in terms of ego permeability; and 18.3\% of high attitude fell in the category of risk-taking.

Table 4 presents a comparison between the descriptive statistics of attitudes and of listening scores in terms of each intelligence group, so that we can understand the differences between intelligence groups according to the two variables of the study, that is, listening proficiency and attitudes. As for the distribution of participants in intelligence profiles, 30 of the participants fell into the visual, interpersonal, and intrapersonal categories with 10 students in each. The other 30 were divided into linguistic (9), kinesthetic (8), logical (7), naturalist (4), and musical (2). The highest score for listening was obtained by the visual group whereas in terms of attitudes, the naturalist group ranked first.

Based on the information in Table 5, the naturalist group rated highest for both risk-taking and ego permeability; the visual group for ego permeability; 
Table 5

Mean Scores of Kinds of Attitude for Each Intelligence Group

\begin{tabular}{lccccc}
\hline $\begin{array}{l}\text { Variables } \\
\text { Participants }\end{array}$ & $\begin{array}{c}\text { Self- } \\
\text { Image }\end{array}$ & Inhibition & $\begin{array}{c}\text { Attitudes } \\
\text { Risk- } \\
\text { Taking }\end{array}$ & $\begin{array}{c}\text { Ego } \\
\text { Permeability }\end{array}$ & $\begin{array}{c}\text { Tolerance to } \\
\text { Ambiguity }\end{array}$ \\
\hline Linguistic & 2.44 & 2.00 & 2.78 & 2.67 & 2.67 \\
Visual & 2.70 & 2.20 & 3.00 & 3.00 & 2.80 \\
Kinesthetic & 2.88 & 2.38 & 2.75 & 2.63 & 3.00 \\
Logical & 2.29 & 2.86 & 2.86 & 2.71 & 3.14 \\
Interpersonal & 2.70 & 2.70 & 3.30 & 2.80 & 3.20 \\
Intrapersonal & 2.70 & 2.30 & 2.90 & 2.80 & 3.00 \\
Musical & 2.50 & 2.00 & 3.00 & 2.50 & 2.50 \\
Naturalist & 2.75 & 2.75 & 3.50 & 3.00 & 3.00 \\
\hline
\end{tabular}

the logical group for inhibition; and the interpersonal group's tolerance to ambiguity was estimated as the highest value for them. In addition to the naturalists, the linguistic and musical groups were also found to gain the highest scores for risk-taking. Tolerance to ambiguity was estimated as the most developed attribute for both the interpersonal and the intrapersonal groups. As for self-image, the kinesthetic intelligence group scored the highest, indicating that they had higher self-image in language-learning than other MI groups, thus facing less potential difficulty (Orwig, 1999).

Finally, the relationship of MIs with listening proficiency and attitudes was investigated using the Pearson product-moment correlation coefficient. As shown in Table 6, the findings indicated no correlation between MIs and listening $(r=.079)$. Also, although there was no significant difference between MIs and the rate of total attitudes $(r=.205)$, as the findings suggest, some types of attitudes are significantly correlated with one another $(p=0.01)$. For example, significant correlations were found between self-image and inhibition (.621), self-image and risk-taking (.429), inhibition and risk-taking (.502), inhibition and tolerance to ambiguity (.405), and risk-taking and tolerance to ambiguity (.347).

\section{Conclusion}

As the results of the study suggest, no significant relationship was found between MIs profiles and listening comprehension (research question 1). Such a conclusion does not confirm the results of Iranian studies (Mahdavy, 2008; Yeganehfar, 2005) that found a relationship between some of the MIs and listening proficiency. However, the results of the present study are to some extent in agreement with studies that did not find a significant rela- 
Table 6

Results of Correlations Between Mls and Listening and Attitudes $(N=60)$

\begin{tabular}{|c|c|c|c|c|c|c|c|c|}
\hline Variables & Statistics & Mls & $S I$ & Inh & $R T$ & $E P$ & $A T$ & Listening \\
\hline \multirow[t]{2}{*}{ Mls } & $\begin{array}{l}\text { Pearson } \\
\text { Correlation }\end{array}$ & 1 & .065 & .175 & .219 & .039 & .153 & .079 \\
\hline & Sig. (2-tailed) & & .623 & .182 & .093 & .769 & .242 & .549 \\
\hline \multirow[t]{2}{*}{ SI } & $\begin{array}{l}\text { Pearson } \\
\text { Correlation }\end{array}$ & .065 & 1 & $.621^{\star *}$ & $.429^{\star *}$ & .127 & .219 & .034 \\
\hline & Sig. (2-tailed) & .623 & & .000 & .001 & .335 & .093 & .796 \\
\hline \multirow[t]{2}{*}{ Inh } & $\begin{array}{l}\text { Pearson } \\
\text { Correlation }\end{array}$ & .175 & $.621^{\star *}$ & 1 & $.502^{\star \star}$ & .008 & $.405^{\star \star}$ & -.080 \\
\hline & Sig. (2-tailed) & .182 & .000 & & .000 & .953 & .001 & .544 \\
\hline \multirow[t]{2}{*}{$\mathrm{RT}$} & $\begin{array}{l}\text { Pearson } \\
\text { Correlation }\end{array}$ & .219 & $.429^{\star \star}$ & $.502^{\star \star}$ & 1 & .154 & $.347^{\star *}$ & .172 \\
\hline & Sig. (2-tailed) & .093 & .001 & .000 & & .240 & .007 & .189 \\
\hline \multirow[t]{2}{*}{ EP } & $\begin{array}{l}\text { Pearson } \\
\text { Correlation }\end{array}$ & .039 & .127 & .008 & .154 & 1 & -.092 & .016 \\
\hline & Sig. (2-tailed) & .769 & .335 & .953 & .240 & & .486 & .901 \\
\hline \multirow[t]{2}{*}{ AT } & $\begin{array}{l}\text { Pearson } \\
\text { Correlation }\end{array}$ & .153 & .219 & $.405^{\star *}$ & $.347^{\star *}$ & -.092 & 1 & .039 \\
\hline & Sig. (2-tailed) & .242 & .093 & .001 & .007 & .486 & & .769 \\
\hline \multirow[t]{2}{*}{ Lis } & $\begin{array}{l}\text { Pearson } \\
\text { Correlation }\end{array}$ & .079 & .034 & -.080 & .172 & .016 & .039 & 1 \\
\hline & Sig. (2-tailed) & .549 & .796 & .544 & .189 & .901 & .769 & \\
\hline
\end{tabular}

${ }^{*}$ Correlation is significant at the 0.01 level (2-tailed).

SI=Self Image; Inh=Inhibition; RT=Risk-Taking; EG=Ego Permeability; AT=Ambiguity Tolerance.

tionship between MIs and various aspects of English proficiency (Razmjoo, 2008).

In terms of the possible relationship between MIs and the rate of attitudes (question 2), the findings of the present study do not support such a relationship. However, in some cases, the mean values were very close. For example, the visual and intrapersonal groups were found to have the same rate of attitude (mean score of 13.7). Also, some types of attitudes were found to be significantly related to one another, which is logically suggestive. As a whole, the reason why no significant relationship was found between the variables of the study may be attributable to the small sample size of the intelligence groups.

As a whole, based on the rationale behind the attitude instrument (Orwig, 1999), it can be interpreted that the logical, the naturalist, and both the visual and the naturalist groups who were respectively ranked highest in inhibition, risk-taking and ego permeability were more likely to exhibit those traits, whereas the interpersonal group, which obtained the highest score for 
tolerance of ambiguity, apparently shows less tendency toward that trait. Thus one may expect that the logical group with high inhibition would perform poorly because those defenses may inhibit learning (Brown, 2000). The results of the present study testify to such a claim because a negative relationship was found between inhibition and listening proficiency ( $r=-$ .080). By the same token, the naturalists and the visual groups who were found to be characterized by ego permeability might be expected to experience enhanced language learning (Brown); however, the correlation between listening and ego permeability $(r=.016)$ indicated that such an assumption was not true for the participants in this study. Also, the interpersonal and the intrapersonal groups who were identified with ambiguity tolerance did not show a positive correlation with listening proficiency $(r=.039)$. The kinesthetic group with a high level of self-image could be assumed to be more successful at language-learning (Brown). However, the results of this study showed no relation between these two variables $(r=.034)$. Nevertheless, risktaking showed a small correlation of $r=.172$ with linguistic intelligence. Thus it can be concluded that risk-taking may have a positive relationship with listening proficiency. Such an inference provides support for Mahdavy's (2008) findings, which indicated a significant correlation between linguistic intelligence and listening proficiency.

In sum, the findings of this study are consistent with some other studies altough in certain respects they are incongruent with some others. For example, the present study showed no positive relationship between ambiguity tolerance and scores on the listening test, whereas Naiman, Fröhlich, Stern, and Todesco (1978) found a positive correlation between these two variables. By the same token, the results of the present study do not suggest any positive relationship between self-image and listening scores, whereas Hayati and Ostadan (2008) found a positive correlation between these two variables. Generally speaking, the literature informs us that the existence of such inconsistencies may stem from the fact that "there is often no theoretical basis for predicting which personality variables will be positively or negatively related to which aspects of L2 proficiency" (Ellis, 1994, p. 519).

\section{The Authors}

Ma'ssoumeh Bemani Naeini is a doctoral candidate in TESL at Universiti Sains Malaysia (USM). She is a faculty member of the Islamic Azad University-Mashhad Branch, Iran and has published university course books in the areas of error analysis and ESP, as well as articles in international journals. She has presented papers on aspects of applied linguistics at both national and international conferences.

Ambigapathy Pandian is a professor and Dean of the School of Languages, Literacies and Translation at Universiti Sains Malaysia. He is also a research fellow at the National Higher Education Research Institute. He has written many books and articles in local and international journals. His areas of specialization include literacy, reading, TESL, sociolinguistics, and higher education. 


\section{References}

Akbari, R., \& Hosseini, K. (2008). Multiple intelligences and language learning strategies: Investigating possible relations. System, 36(2), 141-155

Armstrong, T. (2000). Multiple intelligences in the classroom (2nd ed.). Arlington, VA: Association for Supervision and Curriculum Development.

Arnold, J., \& Fonseca, M.C. (2004). Multiple intelligence theory and foreign language learning: A brain-based perspective. International Journal of English Studies, 4(1), 119-136.

Brown, H.D. (1973). Affective variables in second language acquisition. Language Learning, 23, 231-244.

Brown, H.D. (2000). Principles of language learning and teaching. New York: Longman.

Campbell, L. (1997). Variations on a theme: How teachers interpret MI theory. Leadership, 55(1). Retrieved 26 July, 2010, from:

http://www.ascd.org/publications/educational-leadership/sept97/vol55/num01/ Variations-on-a-Theme $\% \mathrm{E} 2 \% 80 \% 94 \mathrm{How}$-Teachers-Interpret-MI-Theory.aspx

Carter, R., \& Nunan, D. (2001). The Cambridge guide to teaching English to speakers of other languages. Cambridge, UK: Cambridge University Press.

Chamot, A.U., \& Kupper, L. (1989). Learning strategies in foreign language instruction. Foreign Language Annals, 22, 13-24.

Chastain, K. (1988). Developing second-language skills theory and practice. San Diego, CA: Harcourt Brace Jovanovich.

Christison, M.A. (1996). Teaching and learning language through Multiple Intelligences. TESOL Journal, 6, 10-14.

Christison, M.A. (1998). An introduction to multiple intelligence theory and second language learning. In J.M. Reid (Ed.), Understanding learning styles in second language classrooms (pp. 1-14). Upper Saddle River, NJ: Prentice Hall Regents.

Christison, M.A., \& Kennedy, D. (1999). Multiple intelligences: Theory and practice in adult ESL. ERIC Digest. Washington, DC: National Clearinghouse for ESL Literacy Education. (ERIC Document Reporduction Service No. ED 441350)

Cohen, A.D. (2003). The learner's side of foreign language learning: Where do styles, strategies and tasks meet? International Review of Applied Linguistics in Language Teaching, 41(4), 279-291.

Cohen, J. (1988). Statistical power analysis for the behavioral sciences (2nd ed.). Hillsdale, NJ: Erlbaum.

Coopersmith, S. (1967). The antecedents of self-esteem. San Francisco, CA: W.H. Freeman.

Ehrman, M. (1996). Understanding second language learning difficulties. Thousand Oaks, CA: Sage.

Ellis, R. (1994). The study of second language acquisition. Oxford, UK: Oxford University Press.

Feyten, C.M. (1991). The power of listening ability: An overlooked dimension in language acquisition. Modern Language Journal, 75, 173-80.

Gardner, H. (1983). Frames of mind: The theory of multiple intelligences. New York: Basic Books.

Gardner, H. (1991). The unschooled mind: How children think and how schools should teach. New York: Basic Books.

Gardner, H. (1993). Multiple intelligences: The theory in practice. New York: Basic Books.

Ghasemi, P. (1996). The study of second grade of guidance school English textbook from teachers' point of view and students' educational development in Shiraz. Unpublished master's thesis, University of Tarbiat Moalem, Tehran.

Goh, C.C.M. (2000). A cognitive perspective on language learners' listening comprehension problems. System, 28, 55-75.

Hassan, A.S. (2000). Learners' perception of listening comprehension problems. Language, Culture and Curriculum, 13(2), 137-153. 
Hassanpour, M. (1999). Science students' use of language learning strategies and its relation to motivation, attitude, and gender. Unpublished master's thesis, Shiraz Islamic Azad University, Shiraz.

Hassaskhah, J. (2009). There is never any one right way to teach! A case of "multiple intelligences." Iranian EFL Journal Quarterly, 4, 110-133.

Hayati, M., \& Ostadian, M. (2008). The relationship between self-esteem and listening comprehension of EFL students. Glossa, 3(2), 300-312. Retrieved 1 August, 2010, from: http://bibliotecavirtualut.suagm.edu/Glossa2/Journal/jun2008/The_Relationship_ between_Self-esteem.pdf

Holmes, J. (1992). An introduction to sociolinguistics. London: Longman.

Horwitz, E.K. (1995). Student affective reaction and the teaching and learning of foreign languages. International Journal of Educational Research, 23(7), 573-579.

Hosseini, C. (2003). The relationship between Iranian EFL students multiple intelligence and their use of language learning strategies. Unpublished master's thesis, Tarbiat Moalem University, Tehran.

Huitt, W. (2004). Self-concept and self-esteem. Educational Psychology Interactive. Retrieved July 2, 2010, from: http://www.edpsycinteractive.org/topics/regsys/self.html

Krashen, S.D. (1982). Principle and practice in second language acquisition. Oxford, UK: Pergamon.

Krathwohl, D.R., Bloom, B., \& Masia, B.B. (1964). Taxonomy of educational objectives: The classification of educational goals. Handbook H: Affective Domain. New York: David McKay.

Lazaer, D. (1999). Eight ways of teaching: The artistry of teaching with multiple intelligences. Skylight Publishing.

Lin, P.Y. (2000). Multiple intelligence theory and English language teaching [electronic version]. Retrieved December 12, 2007, from: http:/ /highschool.english.nccu.edu.tw/paper/ying.doc

Mahdavy, B. (2008). The role of multiple intelligences (MI) in listening proficiency: A comparison of TOEFL and IELTS listening tests from an MI perspective. Asian EFL Journal, 10(3), 109-126.

Marefat, F. (2007). Multiple intelligences: Voices from an EFL writing class. Pazhuhesh-e Zabanha-ye Khareji, 32, 145-162.

Mazandarani, S. (1998). The study of curriculum development of high schools with emphasis on the experts' view in Gorgan Province. Unpublished master's thesis, University of Tarbiat Moalem, Tehran.

McKenzie, W. (1999). Multiple intelligences survey. Retrieved 24 July, 2010, from: $\mathrm{http}: / /$ surfaquarium.com/MI/inventory.htm

McKenzie, W. (2002). Multiple intelligences and instructional technology. Eugene, OR: ISTE.

Naiman, N., Fröhlich, M., Stern, H.H., \& Todesco, A. (1978). The good language learner. Toronto, ON: OISE Press.

Nunan, D. (1988). The learner-centered curriculum. Cambridge, UK: Cambridge University Press.

O'Malley, J.M., \& Chamot, A.U. (1990). Learning strategies in second language acquisition. Cambridge, UK: Cambridge University Press.

Orwig, C.J. (1999). Prepare for language learning. Retrieved August 2, 2010, from: http://www.sil.org/lingualinks/LANGUAGELEARNING/PrepareForLanguageLearning/ PrepareForLanguageLearning.htm

Oxford, R.L. (1990). Language learning strategies: What every teacher should know. Boston, MA: Heinle \& Heinle.

Pallant, J. (2007). SPSS survival manual: A step-by-step guide to data analysis using SPSS for Windows (Version 15, 3rd. ed.). Milton Keynes, UK: Open University Press.

Powers, S., \& Sanchez, V.V. (1982). Correlates of self-esteem of Mexican American adolescents. Psychological Reports, 51, 771-774.

Rahimi, A., \& Abedini, A. (2009). The interface between EFL learners' self-efficacy concerning listening comprehension and listening proficiency. Novitas-ROYAL, 3(1), 14-28. 
Razmjoo, S.A. (2008). On the relationship between multiple intelligences and language proficiency. Reading Matrix: An International Online Journal, 8(2), 155-174.

Razmjoo, S.A., Sahragard, R., \& Sadri, M. (2009). On the relationship between multiple intelligences, vocabulary learning knowledge and vocabulary learning strategies among the Iranian EFL learners. Iranian EFL Journal Quarterly, 3, 82-110.

Reid, J. (Ed.). (1998). Understanding learning styles in the second language classroom. Upper Saddle River, NJ: Prentice Hall Regents.

Rifkin, B. (2000). Revisiting beliefs about foreign language learning. Foreign Language Annals, 33(4), 394-408.

Sadeghi Bennis, A.R.. (2005). ESP in Iran: A transition from present state. Paper presented at the first national ESP/EAP conference, Tehran.

Sadighi, F., \& Zarafshan, M.A. (2006). Effects of attitude and motivation on the use of language learning strategies by Iranian EFL university students. Journal of Social Sciences and Humanities of Shiraz University, 23(1), 71-80.

Sadler-Smith, E. (2001). The relationship between learning style and cognitive style. Personality and Individual Differences, 30, 609-616.

Sarnoff, I. (1970). Social attitudes and the resolution of motivational conflict. Harmondsworth, UK: Penguin.

Schumann, J.H. (1997). The neurobiology of affect in language. Boston, MA: Blackwell.

Sedaghat, M. (2001). The effects of attitudes, motivation (instrumental and integrative) and proficiency level on the use of listening comprehension strategies by Iranian female EFL students. Unpublished doctoral dissertation, Shiraz University.

Smith, M.K. (2002). Howard Gardner, multiple intelligences and education. Encyclopedia of Informal Education. Retrieved July 29, 2010, from: http://www.infed.org/thinkers/gardner.htm

Talebinezhad, M.R., \& Sadeghi Benis, A.R. (2005). Non-academic L2 users: A neglected research pool in ELT in Iran. Linguistik Online, 25(4). Retrieved August 1, 2010, from: http://www.linguistik-online.com/25_05/talebinezhadBeniss.html

Teele, S. (2004). Overcoming barricades to reading. Thousand Oaks, CA: Corwin Press.

Vandergrift, L. (2002). "It was nice to see that our predictions were right": Developing metacognition in L2 listening comprehension. Canadian Modern Language Review, 58(4), 555-575.

Vandergrift, L. (2004). Learning to listen or listening to learn. Annual Review of Applied Linguistics, 24, 3-25.

Williams, M., \& Burden, R.L. (1997). Psychology for language teachers: A social constructivist approach. Cambridge, UK: Cambridge University Press.

Willingham, D.T. (2004). Reframing the mind: Howard Gardner became a hero among educators simply by redefining talents as "intelligences." Education Next, 4(3), 19-24. Retrieved July 20,2010, from: http:/ / educationnext.org/files/ednext20043_18.pdf

Yeganehfar, B. (2005). Investigating the relationship between proficiency in a foreign language and multiple intelligences. Unpublished master's thesis, University of Allameh Tabatabaei, Tehran. 